RESEARCH ARTICLE

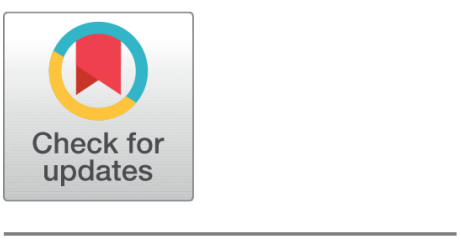

open ACCESS

Received: 22.12 .2020

Accepted: 09.03.2021

Published: 31.03 .2021

Citation: Sheeba T, Ramani Bai M (2021) Feeding preference and reproductive fitness of Rhyzopertha dominica (Fabricius, 1792) in a choice-based feed paradigm. Indian Journal of Science and Technology 14(10): 850-857. https://doi.org/ 10.17485/IJST/v14i10.2281

* Corresponding author.

sheebadon195@gmail.com

Funding: None

Competing Interests: None

Copyright: (c) 2021 Sheeba \& Ramani Bai. This is an open access article distributed under the terms of the Creative Commons Attribution License, which permits unrestricted use, distribution, and reproduction in any medium, provided the original author and source are credited.

Published By Indian Society for Education and Environment (iSee)

ISSN

Print: 0974-6846

Electronic: 0974-5645

\section{Feeding preference and reproductive fitness of Rhyzopertha dominica (Fabricius, 1792) in a choice-based feed paradigm}

\author{
T Sheeba ${ }^{1 *}$, M Ramani Bai ${ }^{2}$ \\ 1 Department of Zoology, Scott Christian College, Manonmanium Sundaranar University, \\ Thirunelveli, Tamil Nadu, India \\ 2 Department of Zoology, Muslim Arts College, Thiruvithamcode, Tamil Nadu, India
}

\section{Abstract}

Objective: This study is designed to understand the feeding preference of $R$. dominica, when three grains and their flours are provided in a choice- paradigm, constructed in the form of a poly vinyl chloride tunnel, in which feed materials are made available at random. Methods and Analysis: A total of 200 beetles were released into the choice-paradigm, and the number of beetles in each feed was counted once in every $24 \mathrm{~h}$. When the beetles in the choice chamber were enumerated after 96 h, 26 percent of the released beetles were found in wheat grain; $25 \%$ in wheat flour; 12 in rice; 11 in chick pea; 10 in rice and chick pea flours and $6 \%$ in the outer tunnel without opting for any feed. On the basis of the feed on which $R$. dominica were reared, changes were observed in selected key biological characteristics. Findings: The research findings showed that wheat and wheat flour were preferred against rice, chick-pea and their flours. The incubation period increased significantly (51\%) when reared in chick pea flour. In beetles reared on this feed, total larval period increased by $39 \%$, pupal period by $31 \%$ and total developmental period by $39 \%$. The fecundity decreased by $11 \%$, whereas, male and female longevities respectively by $20 \%$ and $24 \%$. Egg hatching was not much affected by the type of feed. Hatchability was $92 \%$ for wheat flour and $97 \%$ for rice and chick pea grains. Novelty: $R$. dominica, a primary pest of stored wheat, seemed to possess the evolutionary plasticity to survive in a variety of feed materials when the primary diet is not available.

Keywords: Rhyzopertha dominica; Triticum aestivum; Oryza sativa; Cicer arietinum; feeding preference

\section{Introduction}

Rhyzopertha dominica (Fabricius, 1792) (Coleoptera: Bostrichidae), the lesser grain borer, a primary pest of stored grain, mainly wheat, occurs all over the world and survives on a variety of other grains like rice, sorghum, oats, pearl, millet, malt, barley, chickpeas, peanuts and beans ${ }^{(1)}$ Studies were conducted to understand the influence of the feed type on the development of $R$. dominica and subsequent progeny 
production $^{(2-6)}$. The larvae and adults of this insect attack whole grains and cause extensive damage ${ }^{(7)}$. The adults chew grains voraciously which not only cause weight $\operatorname{loss}^{(8)}$ but also reduces germination and vigour of the grains ${ }^{(9)} \cdot R$. dominica can attack a huge variety of materials other than stored grains such as dried fruits, seeds, drugs, cork, timber and paper products. It can also facilitate infestation by secondary pests and fungi ${ }^{(10)}$. The larvae and adults of $R$. dominica spend most of their life inside the kernel so it is difficult to detect the attack by $R$. dominica at the initial stage of infestation and it is difficult to control the attack at later stages. In case of serious infestation of this pest in the flours, the flour turns yellowish and mouldy, has a pungent, obnoxious odour and becomes unfit for human consumption ${ }^{(11)}$. Prevention of insect induced losses in stored products is of paramount importance, so the biology, habits and habitats of these insects must be investigated in detail.

Wheat is commonly stored together with other grains such as barley, rye, oats and triticale. It is important to assess the influence of smaller grains on progeny production and feeding preferences of $R$. dominica. Small grains contain major nutritive groups, important for the development and fitness of $R$. dominica. Wheat, barley, rye, oats and triticale differ in the amount of proteins, starch and other nutrients they possess but $R$. dominica has the genetic plasticity to thrive independently in each of these grains ${ }^{(12)}$. The major objective of the present study is to assess the feeding preferences of $R$. dominica for grains such as wheat and rice and a legume chick-pea and their flours in a free choice paradigm and to evaluate their fitness by assessing certain key biological traits, when raised individually on the six types of feed materials.

\section{Materials and Methods}

\subsection{Test insects}

Adults of $R$. dominica of both sexes and 2 to 4 weeks old, used in the experiments, were reared in the Zoology Research Laboratory of Scott Christian College, Nagercoil, India $\left(8.1833^{\circ} \mathrm{N}, 77.4119^{\circ} \mathrm{E}\right)$ at a temperature level of $26 \pm 1^{\circ} \mathrm{C}$ and relative humidity $(\mathrm{RH}), 60 \pm 5 \%$. R. dominica adults were sexed based on the description given in ${ }^{(13)}$. The last exposed abdominal tergum of males is uniformly brown and that of the female is usually pale yellow.

\subsection{Diet commodities}

R. dominica were reared on two commercially available small grain varieties (wheat (VL 832), rice (AD127) and a legume chick pea (JGK5)) and on the flours of these three seeds. Wheat grain consists of $27.6 \mathrm{~g}$ of protein/ 100g; 9.2,fat; 44.7, carbohydrates; $22 \mathrm{mg} / 100 \mathrm{gm}$ vitamin $\mathrm{E} ; 2.01$, thiamine; 0.72 , riboflavin and $45 \mathrm{mg}$, niacin ${ }^{(14)}$. Rice consists of 33 percent Amylase as dry matter; Iron, 2.32mg/100g; Zinc,5.4mg; 0.475,Thiamine; Riboflavin, 0.091 and Niacin, $5.322^{(15)}$. Chick pea carries 32 percent starch;16.7,Protein;20,Amylase;15.6 dietary fibre; 2.32mg/100gm Iron;5.4 Zinc; 230,Potassium; 0.475, Thiamine; 0.091,Riboflavin and 5.322, Niacin (Wood and Grusak,2007) ${ }^{(16)}$. Harvested fresh seeds were put in the refrigerator at $4{ }^{\circ} \mathrm{C}$. Before introducing $R$. dominica adults, the grains were removed from the refrigerator brought to ambient temperature and cleaned by hand to remove any debris or chaff present. Plastic containers of $200 \mathrm{ml}$ were filled with $50 \mathrm{~g}$ of grains. Six pairs of adults of $R$. dominica were released into each vessel for studying the different biological key factors. Vessels were then closed with a serviette fastened with a rubber band. The egg-to-adult development of $R$. dominica was followed for eight weeks.

\subsection{Choice- based diet preference studies}

Food preference of $R$. dominica was studied in detail by providing the six different feed types to the adult beetles in a randomized, six pronged free choice tunnel system. $R$. dominica adults were tested for their food preference in a tunnel constructed with polyvinyl chloride pipes of 2" diameter. The food tunnel pattern designed by ${ }^{(17)}$ was followed. The food chambers consisted of $800 \mathrm{ml}$ polythene covers. These covers were fastened to 1' long vertical pipes using fasteners. The joints were made tight to prevent the beetles from escaping out. In each polythene cover, $25 \mathrm{~g}$ of grain or flour is taken, taking care that the feed material remains at the bottom of the cover. Care was taken to ensure that the diet particles did not get overlaid on the interior of the food cover in the mouth region, so that the chemical stimulus of none of the diet materials superseded the others.

\subsection{Loading of diet material}

The diet was loaded at random into the polythene covers. Each vertical pipe holding the polythene covers were numbered. Separate numbers were assigned to each diet, as well as each diet holder. The diet materials were assigned using a six numbered dice. For each diet holder the dice was rolled twice. The first number on the dice referred to the number of the diet and the second number referred to the number of the polythene dispenser. If the first number was 2 , that referred to the rice grain and if the second number is 4 , it indicated that the fourth dispenser be loaded with rice. If the same numbers were repeated, 
the dice was rolled again. Thus, wheat, rice, chickpea and their flours were loaded into the polythene bags and fastened to the vertical pipes. This system completely randomized the diet holders and thus the results obtained were without any bias as to the position of the feed material within the choice-based feeder paradigm. The vertical pipes were fitted with ' $\mathrm{T}$ ' joints which were connected by horizontal pipes, about 2' long. The horizontal pipe structure was provided with a ' $\mathrm{T}$ ' joint exactly in the middle, which was connected to a ' ' long vertical pipe which served as the beetle vent. The beetle vent was closed with an end cap. The tunnel system was lengthy enough to ensure that the chemical signals from any of the diet materials were not available at the beetle inlet vent.

\subsection{Introduction of $R$. dominica adults}

Exactly 200 R. dominica adults were taken in separate polythene bags for introduction into the choice-paradigm. The beetles were initially taken in a long polythene bag ( 12 "X 9 "). The beetles were allowed to settle down inside the cover for about 1 hour. The long cover in which the insects are taken is collapsed and closed in the middle region of the cover using a cloth band. This enabled the beetles to remain at the bottom of the cover leaving the tip of the cover free, to be fastened to the inlet pipe. After 1 hour, the cover was tightly fastened to the inlet pipe using a sticky tape. The cover was allowed to remain as such for about 1 hour. Then the band in the middle was removed and the constrictions in the cover were straightened out, for the free movement of the beetles. Timing of beetle movement was calculated from this time of release of beetles and in this way the beetles showed unbiased movements towards the food materials of their choice. The time at which the beetles were allowed into the system was properly recorded and number of beetles preferring a particular feed material were counted after 24, 48, 72and 96 hours. Only the beetles that have fully entered a particular feed material dispenser were deemed to have preferred that feed. The percentage of beetles in each feed was separately recorded. The beetles were allowed into the choice chamber through the 2' long pipe connected to a long horizontal tube at the central location. Beetles remaining outside the six feed types, in the tunnel system were recorded as stray beetles. Analysis of variance and Tukey's tests were carried out to understand the attraction potential of the different feed types towards $R$. dominica adults.

\subsection{Life history traits}

Biological observations such as incubation, larval, pupal and total developmental periods, adult male and female longevities, fecundity and fitness were studied in detail. Examination of the influence of the different grain species on the emergence of the progeny of $R$. dominica, was based on the modified method of ${ }^{(10)}$.

\subsection{Incubation period}

Three pairs of newly emerged adults were transferred into glass petriplates. The pair that completed its development in a particular feed type was always allowed into the same feed type to understand the impact of that feed type on their biological characteristics. The beetles were allowed to mate and oviposit for about 15 days. Flour / grain and legume samples containing eggs were sieved carefully through a $90 \mathrm{~mm}$ mesh and the eggs were separated out daily with the help of a fine brush by examining under a dissection microscope. Eggs deposited on the samples were transferred to petridishes using a fine brush and small debris, if any were removed carefully. Three replications of each feed type were maintained. Incubation period was recorded as the duration of time taken by the freshly laid eggs to hatch out, which was recognized by the dark extremities of the larva seen through the egg chorion.

\subsection{Larval period}

The larval duration was recorded as the time (in days) taken from the hatching of the egg till the pupation of the last instar grub. To determine the number of larval instars and the duration of each instar, six replicates of six eggs on the same day were collected in petriplates. This was done to eliminate any error that may occur when eggs laid on different days were mixed. These eggs hatched almost on the same day. The growth of the grub was carefully noticed each day and the larvae were kept in separate petri dishes marked day-wise. The duration of the different instars were calculated by observing the moulted skin of the larvae in the feed. The process was carefully continued till all the larvae pupated

\subsection{Pupal periods}

The pre-pupal stage does not involve moulting and can be distinguished from the fully mature larva by its elongated cylindrical shape and extended head. The corrected larval period was calculated by subtracting the pre-pupal period from the total larval 
period. The periodicity of six replicates of six pupae was followed to record the pupal period which extended from the formation of the pupa to the eclosion of the adult. Pupal period was recorded from the formation of pupa till the eclosion of the adult.

\subsection{Adult longevity and oviposition periods}

The life span of $R$. dominica adults was recorded by confining male and female adults in a glass Petri plate with a specific feed type. Six such plates were maintained for each diet with 10 pairs of adults in each. Male and Female longevities were separately followed and recorded. In the female beetles, the adult longevity included the pre-oviposition, oviposition and the post-oviposition periods.

\subsection{Fecundity}

Fecundity was recorded by counting the number of eggs laid during the oviposition period of a female. Oviposition started after the first mating took place. Mating initiated the ovipositional process. The eggs were laid singly in the flour material. The flour material was sieved and the eggs were recovered. From the grains and the legume, the eggs were collected using a small brush and a magnifying lens, after moving the grains carefully to one part of the container. The egg count in each diet was separately recorded. Egg counting was continued throughout the ovipositional period of a female. Counting was discontinued only after ascertaining that all the eggs to be laid are fully deposited. When eggs were not laid for a period of 10-12 days, it was presumed that the egg laying has fully stopped.

\section{Results}

After 24 hours of introducing the R. dominica beetles in the diet preference chamber, $18 \%$ of the beetles preferred wheat grain, $7 \%$ of beetles preferred rice and chickpea. The number of beetles found in wheat flour is $30 \pm 6$, the number preferred rice flour and chickpea flour is $14 \pm 3$ and $15 \pm 3.38 \%$ of beetles were found as stray beetles. $R$. dominica adults preferred to stay in wheat grain when checked after 96 hours. About 26 percent of the beetles stayed in wheat grains and 25 percent in wheat flour. Preferences were much limited for rice flour (10 percent), Chickpea (11 percent) and chickpea flour (10percent). Only 6 percent of beetle stayed outside food. In the count made at 24 hour, about 38 percent beetles stayed out in the tunnel, not preferring any food material (Table 1 ).

Fecundity is high in wheat (427 eggs) and wheat flour (425 eggs) and about 15 percent less in rice flour. The total larval period in rice was $27 \pm 4$ and the highest larval period of $45 \pm 4$ days was recorded in the legume chickpea. The highest pupal periodicity was recorded in chickpea $(13 \pm 2)$ and the lowest pupal periodicity was recorded in wheat grain and its flour $(8 \pm 1.87$ $\& 8 \pm 1.04$ ). The incubation period was lowest (7days) in wheat and highest (10days) in chickpea flour. The total developmental period was 55 percent higher in chickpea compared to wheat grain (Table 2).

Table 1. Analysis of variance and Tukey testing of choice -based food preference in $R$. dominica with the release of 200 beetles $(\mathrm{n}=6 ; \bar{X} \pm S D)$

\begin{tabular}{lllll}
\hline \multirow{2}{*}{ Feed type } & \multicolumn{4}{c}{ Interval after release (in h) } \\
\cline { 2 - 5 } & 24 & 48 & 72 & 96 \\
\hline Wheat & ${ }^{\mathrm{b}} 36 \pm 4(18)$ & ${ }^{\mathrm{b}} 41 \pm 4(20)$ & ${ }^{\mathrm{b}} 48 \pm 3(24)$ & ${ }^{\mathrm{c}} 51 \pm 2(26)$ \\
Rice & ${ }^{\mathrm{a}} 14 \pm 4(7)$ & ${ }^{\mathrm{a}} 18 \pm 4(9)$ & ${ }^{\mathrm{a}} 22 \pm 3(11)$ & ${ }^{\mathrm{a}} 24 \pm 3(12)$ \\
Chick pea & ${ }^{\mathrm{a}} 16 \pm 3(7)$ & ${ }^{\mathrm{a}} 16 \pm 2(8)$ & ${ }^{\mathrm{a}} 18 \pm 0.8(8)$ & ${ }^{\mathrm{a}} 21 \pm 2(10.50)$ \\
Wheat flour & ${ }^{\mathrm{b}} 30 \pm 6(15)$ & ${ }^{\mathrm{b}} 38 \pm 6(14)$ & ${ }^{\mathrm{b}} 46 \pm 4(23)$ & ${ }^{\mathrm{c}} 50 \pm 3(25)$ \\
Rice flour & ${ }^{\mathrm{a}} 14 \pm 3(7)$ & ${ }^{\mathrm{a}} 15 \pm 3(7)$ & ${ }^{\mathrm{a}} 17 \pm 3(8)$ & ${ }^{\mathrm{a}} 21 \pm 2(10)$ \\
Chick pea flour & ${ }^{\mathrm{a}} 15 \pm 3(7)$ & ${ }^{\mathrm{a}} 16 \pm 3(8)$ & ${ }^{\mathrm{a}} 17 \pm 3(8)$ & ${ }^{\mathrm{a}} 21 \pm 2(10)$ \\
Stray beetles & ${ }^{\mathrm{c}} 76 \pm 8(38)$ & ${ }^{\mathrm{c}} 56 \pm 7(28)$ & ${ }^{\mathrm{c}} 32 \pm 5(16)$ & $\mathrm{b} 12 \pm 2(6)$ \\
\hline
\end{tabular}

At the 0.05 level, the population means are significantly different( $\mathrm{F}$ test).

Means super scripted by the same alphabets are not statistically significant(Tukey test)

Percent occurrence of $R$. dominica in each feed type in parentheses

\section{Discussion}

Mechanisms of acceptance of cereal grains or legumes by insect pests of stored products are complex and depend on many factors, such as the physicochemical and biochemical grain properties as well as the insects' capacity for biochemical and 
Table 2. Analysis of Variance and Tukey testing of key biological characteristics of $R$. dominica raised on different feed types $(\bar{X} \pm S D ; \mathrm{n}=6)$

\begin{tabular}{|c|c|c|c|c|c|c|c|c|}
\hline \multirow{2}{*}{$\begin{array}{l}\text { Feed } \\
\text { type }\end{array}$} & \multirow{2}{*}{$\begin{array}{l}\text { Incubation } \\
\text { period }\end{array}$} & \multirow{2}{*}{$\begin{array}{l}\text { Total Larval } \\
\text { period }\end{array}$} & \multirow{2}{*}{$\begin{array}{l}\text { Pupal } \\
\text { period }\end{array}$} & \multirow{3}{*}{$\begin{array}{l}\text { Total develop- } \\
\text { mental } \\
\text { period }\end{array}$} & \multirow{3}{*}{ Fecundity } & \multirow{3}{*}{$\begin{array}{l}\text { No. of eggs } \\
\text { hatched }\end{array}$} & \multicolumn{2}{|c|}{ Adult longevity (Days) } \\
\hline & & & & & & & \multirow{2}{*}{ Male } & \multirow{2}{*}{ Female } \\
\hline Days & & & & & & & & \\
\hline Wheat & ${ }^{a} 7 \pm 2$ & ${ }^{\mathrm{a}} 27 \pm 6$ & $8 \pm 2$ & ${ }^{\mathrm{a}} 45 \pm 7$ & ${ }^{\mathrm{a}} 427 \pm 6$ & $\begin{array}{l}{ }^{\mathrm{a}} 406 \pm 11 \\
(95)\end{array}$ & $242 \pm 5$ & $244 \pm 5$ \\
\hline Rice & ${ }^{c_{9}} \pm 2(31)$ & $\begin{array}{l}{ }^{\mathrm{a}} 27 \pm 4(- \\
56)^{\star}\end{array}$ & $12 \pm 1(57)$ & ${ }^{\mathrm{a}} 51 \pm 2(13)$ & $\begin{array}{l}\mathrm{b}_{375} \pm 15(- \\
12)\end{array}$ & $\begin{array}{l}{ }^{\mathrm{b}_{362}} \pm 18( \\
97)\end{array}$ & $\begin{array}{l}214 \pm 10(- \\
11)\end{array}$ & $\begin{array}{l}212 \pm 3 \quad( \\
13)\end{array}$ \\
\hline $\begin{array}{l}\text { Chick } \\
\text { Pea }\end{array}$ & ${ }^{c_{9}} \pm 2(33)$ & $\mathrm{b}_{45} \pm 4(57$ & $13 \pm 2(73)$ & ${ }^{\mathrm{b}} 69 \pm 3(55)$ & $\begin{array}{l}\mathrm{b}_{373} \pm 16(- \\
13)\end{array}$ & $\begin{array}{l}\mathrm{b}_{360} \pm 14( \\
97)\end{array}$ & $\begin{array}{l}210 \pm 10(- \\
13)\end{array}$ & $\begin{array}{l}210 \pm 6 \quad( \\
14)\end{array}$ \\
\hline $\begin{array}{l}\text { Wheat } \\
\text { flour }\end{array}$ & $\mathrm{b}_{8} \pm 2(15)$ & $\begin{array}{l}{ }^{\mathrm{a}} 28 \pm 3(-4 \\
)^{*}\end{array}$ & $8 \pm 1(0)$ & $\mathrm{a} 44 \pm 3(1)^{*}$ & $\begin{array}{l}\mathrm{a} 425 \pm 26(- \\
0.4)^{*}\end{array}$ & $\begin{array}{l}\text { a } 390 \pm 13( \\
92)\end{array}$ & $\begin{array}{l}234 \pm 8(-3 \\
)^{\star}\end{array}$ & $\begin{array}{l}235 \pm 4(- \\
4)\end{array}$ \\
\hline $\begin{array}{l}\text { Rice } \\
\text { flour }\end{array}$ & $\mathrm{b}_{7} \pm 1(13)$ & $\begin{array}{l}{ }^{a} 30 \pm 3(4 \\
)^{*}\end{array}$ & $9 \pm 1(17)$ & ${ }^{\mathrm{a}} 49 \pm 3(9)^{*}$ & $\begin{array}{l}\mathrm{b}_{365} \pm 14(- \\
15)\end{array}$ & $\begin{array}{l}\mathrm{b}_{352} \pm 13( \\
96)\end{array}$ & $\begin{array}{l}234 \pm 8(-3 \\
)^{\star}\end{array}$ & $\begin{array}{l}231 \pm 4(- \\
5)\end{array}$ \\
\hline $\begin{array}{l}\text { Chick } \\
\text { pea } \\
\text { flour }\end{array}$ & ${ }^{c} 10 \pm 1(51$ & ${ }^{\mathrm{b}} 40 \pm 3(40$ & $10 \pm 1(31)$ & ${ }^{\mathrm{b}} 63 \pm 6(39)$ & $\begin{array}{l}\mathrm{b}_{378} \pm 9(- \\
11)\end{array}$ & $\begin{array}{l}\mathrm{b}_{365} \pm 10( \\
97)\end{array}$ & $\begin{array}{l}193 \pm 8(-20 \\
)\end{array}$ & $\begin{array}{l}185 \pm 7(- \\
24)\end{array}$ \\
\hline
\end{tabular}

At the 0.05 level, the population means are significantly different ( $\mathrm{F}$ test).

Means super scripted by the same alphabets are not statistically significant (Tukey test)

physical adaptation to post-harvest conditions ${ }^{(18)}$. It should be noted that physical and chemical properties of cereal grains have a strong influence on the developmental rate and grain infestation potential of $R$. dominica ${ }^{(19)}$. The authors established the significant effect of wheat variety on the mortality of $R$. dominica, indicating that variation among varieties of a particular grain type can influence the results of Diatomaceous Earth (DE) studies. Variation in DE efficacy among the tested varieties could be attributed to differences in the physical or chemical characteristics of the grain. ${ }^{(19)}$ found that protein content was related to high DE efficacy levels in certain wheat varieties. Kernel size is also likely to play an important role in the efficacy of dust formulations, since better distribution of the DE particles is achieved on smaller kernels compared to larger ones ${ }^{(20)}$. It may be presumed that attraction of $R$. dominica towards any diet type included various grain properties. The studies by ${ }^{(21)}$ showed that grain hardiness decided stronger or weaker infestation by $R$. dominica. $R$. dominica caused a maximum percentage of weight loss in white grams with the highest infestation percentage. The number of eggs laid on white and brown gram varieties was significantly different and this is attributed to variations in seed size and seed coat. Similar results were reported by ${ }^{(22)}$ who revealed that among the grains, the seed size was the main feature that influenced the performance of bruchids on different varieties of pulses and cereals. In the study recorded a lower number of eggs on Lens culinaris (Masoor), Cicer arietinum (gram or chickpea), Hordeum vulgare (barley), Pennisetum glaucum (Pearl millet), and Avena sativa (oat) which were small sized seeds and might be due to the small surface area available to the egg. The insects did not prefer to lay more eggs on these small sized grains. In a study ${ }^{(23)}$ recorded the highest number of eggs on kidney bean (large-sized seed) and maize. The basic reason for this great difference is due to grain size and its surface area and obviously nutritional value of the diet.

The results of an earlier study showed that the highest progeny was found in wheat, which is one of the softest grains. According to ${ }^{(19)}$, smaller size and kernel shape of grain could discourage the lesser grain borer from laying eggs in clusters on the kernels. A study by ${ }^{(1)}$ reported that the texture of larval food can have significant influence on the rate of brood development. It is evident that wheat grain is the greatly preferred feed type of $R$. dominica. About 25 percent of the released beetles settled in wheat grain, 96 hours after releasing 200 beetles into the feed -choice paradigm. Wheat flour was also equally attractive to the beetles. Rice, Chickpea and the flours of these grains attracted about 10-12 percent of the beetles after 96 hours of the feedchoice experiment. About 38 percent of the beetles stayed away from food after 24 hours. But with the passage of time these beetles travelled towards the different preferred food types and only 6.08 percent of beetles remained outside the food even after 96 hours. Wheat grain is the ideal diet of $R$. dominica, which achieves its maximum reproductive success on dry grains especially on wheat ${ }^{(23,24)}$. A study ${ }^{(25)}$ reported that the wheat endosperm is about $83 \%$ of the kernel weight and is a good source of food components such as proteins, carbohydrates and vitamins.

A study by ${ }^{(25)}$ recorded a shorter egg and larval period of $R$. dominica on wheat. Nature always promotes faster development as it improves fitness. There will be a natural instinct among the populations to opt for a system that is comparatively favourable for efficient life cycle modifications. This presumably is one reason why $R$. dominica prefers wheat than other diets. Physical and chemical properties of the grain have a fundamental influence on the food preference of $S$. granarius as recorded by ${ }^{(18)}$. It 
is possible that grain properties like hardness and nutritive content attracted $R$. dominica towards wheat than other diet types. A report by ${ }^{(21)}$ stated that grain hardness represents one of the main reason for feed preference of $R$. dominica.

${ }^{(25)}$ Recorded a shorter egg and larval period of $R$. dominica on wheat. This denotes that $R$. dominica prefers wheat than other diets, because of the balanced and essential nutrients present in wheat than other diet sources. The hardness of grain is one of the physical properties associated with resistance or susceptibility to insect attack ${ }^{(26)}$. The hardness of wheat is comparatively less than the other grain rice and the legume chickpea. The other diet types provided in this experiment are consumed by $R$. dominica when the most preferred diet, wheat grain is not available. Insects are attracted to favorable food sources, but also select alternate food sources at the same time ${ }^{(27)}$. A study by ${ }^{(28)}$ reported the highest rate of progeny production in $R$. dominica reared on triticale, a hybrid of wheat and rye. The reason why $R$. dominica preferred wheat grain is that wheat contains nutrients needed for the normal growth, development, reproduction and fitness of the beetle. This supports the finding of this experiment that, $R$. dominica prefers wheat grain than other provided diets.

Initially the choice - food chamber, perhaps was not familiar to $R$. dominica and many of them waited outside the diet chamber. But once they become accustomed to the food tunnel, they moved to the different feed types preferred by them. The population of $R$. dominica increased in each feed type after $96 \mathrm{~h}$, compared to their presence after 72 hours. The biological characteristics (Table 2) tested were presumably unaffected by the different diet types. Wheat grain is the most preferred diet of $R$. dominica. In a study ${ }^{(29)}$ also reported the highest migration rate of $R$. dominica towards wheat during their whole study period, which is presumably the result of optimal developmental conditions in wheat grains.

The incubation period is lowest ( $7 \pm 2$ days) for eggs laid by $R$. dominica, reared on wheat. In rice fed beetles, the incubation period increased by 4 percent and the corresponding value for chick-pea flour was 51 . This record is similar to that of ${ }^{(30)}$ who found that the incubation period in $R$. dominica was shorter when reared on wheat and broken wheat as wheat is its most favorable food source, but it was quite higher on paddy. The total larval period increased in larvae hatched out from eggs laid by $R$. dominica reared on chick-pea grains /flour.This is because of the high moisture content and nutrition found in wheat. This finding is supported by the findings of Jagannatham et al. (2014) who recorded high protein content in wheat flour. The water binding capacity of wheat flour $(113.43 \pm 1.00 \%)$ is higher than chickpea flour $(101.81 \pm 1.83 \%)$. This property of active products of wheat may make the grain softer than the other selected diet varieties. Hence the larvae of $R$. dominica consume lesser days to complete its stage. The larval periods pertaining to feeds such as wheat and rice, and their flours were almost similar with statistically non significant differences between them (' $\mathrm{T}$ ' test and Tukey test). Similar results were obtained in Lasioderma serricorne $\mathrm{F}$. whose adult stage was completed in a shorter time on wheat flour compared to the other sources and this faster development could be because of the balanced and essential nutrients present in wheat ${ }^{(31)}$. Wheat flour is nutritionally rich in valuable proteins, complex carbohydrates, vitamins and minerals ${ }^{(32)}$ necessary for growth and development of L. serricorne, and the flour could also lack the defensive chemicals present in other hosts tested. The total developmental period was $49 \pm 7$ days in $R$. dominica that developed as the progeny of wheat fed beetles. The total developmental period increased by 55 percent in chick-pea fed $R$. dominica and 40 percent in beetles fed with chick-pea flour. The findings are in line with ${ }^{(33)}$, who studied the egg, larval and pupal development time of the cigarette beetle, L. serricorne on seven food sources like ground chilli, paprika, cayenne pepper, chewing leaf tobacco, cigar tobacco, commercial insect bait and wheat flour which recorded varied durations from 3 to 5,38 to 92 and 4 to 18 days, respectively, with the least duration for wheat flour.

The highest fecundity was recorded in $R$. dominica grown on wheat grains $(427 \pm 6)$. Fecundity was significantly lower in other diet types. The fecundity was similar for wheat grain as well as flour. Fecundity is the main fitness trait of any organism. The progeny of any organism basically depends on its fecundity, which determines its fitness. The fittest organism leaves behind the maximum progeny. Studies by ${ }^{(34)}$ and ${ }^{(35)}$ reported that the quality of feed for animals is considered to be a critical factor that affect feeding preference and reproductive performance of insect pests.

Hatchability of eggs varied from 92 percent (wheat flour) to 97 percent (Rice grain). Minimum statistically non significant variation was recorded with reference to hatchability of $R$. dominica eggs laid by beetles raised on six different feed types. Our findings are in line with ${ }^{(27)}$ who recorded R.dominica egg period as 5 to 9 days, larval and pupal period as 24 to 45 days on whole wheat.

\section{Conclusion}

R. dominica is an internal feeder of stored product with a wide spectrum of feeding habit. If the preferred food is not available, $R$. dominica can survive with the available food, as it can survive on various other types of food such as, oats.rye, triticale and the like. Pests that feed on a particular type of food cannot sustain if there is short supply of that favored food. The population of such insects may become gradually eradicated because of unavailability of the staple food. But the pests with the wide spectrum feeding habits like $R$. dominica can sustain well even when the preferred food is not available. Their population size may get diminished when preferred food is not consumed, but they will regain the population size when the preferred food is again 
consumed. Lesser grain borer, $R$. dominica is an important pest of stored wheat. The damage caused by this pest resulted in substantial damage to wheat grains. Information on biology and feeding preference of $R$. dominica helps in advising proper management programme for this stored product pest and similar pests.

\section{Acknowledgement}

TS conveys sincere gratitude to the Principal, Scott Christian College Nagerciol, Tamilnadu, India, Head, Department of Zoology, for the laboratory facilities extended.

\section{References}

1) Edde PA. A review of the biology and control of Rhyzopertha dominica (F.) the lesser grain borer. Journal of Stored Products Research. 2012;48:1-18. Available from: https://dx.doi.org/10.1016/j.jspr.2011.08.007.

2) Arthur FH, Ondier GO, Siebenmorgen TJ. Impact on Rhyzopertha dominica on quality parameters of milled rice. Journal of Stored Product Research. 2012;48:137-142. Available from: https://doi.org/10.1016/j.jspr.2011.10.010.

3) Arthur FH, Starkus L, Smith CM, Phillips TW. Methodology for determining susceptibility of rough rice to Rhyzopertha dominica and Sitotroga cerealella. Journal of Pest Science. 2013;86(3):499-505. Available from: https://dx.doi.org/10.1007/s10340-013-0481-2.

4) Astuti LP, Mudjiono G, Ch SR, Rahardjo BT. Susceptibility of Milled Rice Varieties to the Lesser Grain Borer (Rhyzopertha dominica, F). Journal of Agricultural Science. 2013;5(2):145-149. Available from: https://dx.doi.org/10.5539/jas.v5n2p145.

5) Metwaly MR, Abou-Ghadir MF, Abdu-Allah GM, K ANM. Susceptibility of certain wheat varities to the infestation by Rhyzopertha dominica (f.) and Tribolium confusum(du Val)". Journal of Phytopathology and Management. 2015;2(3):1-8. Available from: http://ppmj.net/index.php/ppmj/article/view/ 38.

6) Pires EM, Nogueira RM, Pina DS, Manica CLM, Faroni LRA, Moreira PSA. Walking stability of Rhyzopertha dominica (Fabricius, 1792) (Coleoptera: Bostrichidae). Brazilian Journal of Biology. 2016;76(3):568-576. Available from: https://dx.doi.org/10.1590/1519-6984.16914.

7) Williams HJ, Silverstein RM, Burkholder WE, Khorramshahi A. Dominicalure 1 and 2: Components of aggregation pheromone from male lesser grain borerRhyzopertha dominica (F.) (Coleoptera: Bostrichidae). Journal of Chemical Ecology. 1981;7(4):759-780. Available from: https://dx.doi.org/10.1007/ bf00990308.

8) Brower JH, Tilton EW. Weight loss of wheat infested with gamma-radiated Sitophilus oryzae (L.) and Rhyzopertha dominica (F.). Journal of Stored Products Research. 1973;9(1):37-41. Available from: https://dx.doi.org/10.1016/0022-474x(73)90037-4.

9) Jilani G, Saxena RC, Khan AA. Ethylene production as an indicator of germination and vigor loss in stored rice seed infested by Rhyzopertha dominica (F.) (Coleoptera: Bostrychidae). Journal of Stored Products Research. 1989;25(3):175-178. Available from: https://dx.doi.org/10.1016/0022-474x(89)90040-4.

10) Mukherjee PS, Nandi B. Insect B fungus associations influencing seed determination in storage. JMycopathologyRes. 1993;31:87-92.

11) Egal S, Hounsa A, Gong YY, Turner PC, Wild CP, Hall AJ, et al. Dietary exposure to aflatoxin from maize and groundnut in young children from Benin and Togo, West Africa. International Journal of Food Microbiology. 2005;104(2):215-224. Available from: https://dx.doi.org/10.1016/j.ijfoodmicro.2005.03.004.

12) Serna-Saldivar O. Chemical composition of cereal grains. In: O SS, editor. Cereal Grains: Properties. Processing and Nutritional Attributes;vol. 3. Taylor \& Francis Group. 2010;p. 81-108.

13) Stemley PG, Wilbur DA. A Color Characteristic for Sexing Live Adult Lesser Grain Borers1. Journal of Economic Entomology. 1966;59(3):760-761. Available from: https://dx.doi.org/10.1093/jee/59.3.760.

14) Kumar P, Yadava RK, Gollen B, Kumar S, Verma RK, Yadav S. Nutritional Contents and Medicinal Properties of Wheat: A Review". Life Sciences and Medicine Research. 2011;22.

15) Kennedy G, Burlingame B. Analysis of food composition data on rice from a plant genetic resources perspective. Food Chemistry. 2003;80:589-596. Available from: https://dx.doi.org/10.1016/s0308-8146(02)00507-1.

16) Wood J, Grusak MH. Nutritional value of chickpea . In: Yadav SS, editor. Chickpea breeding and management. 2007.

17) Kiruba S. Studies on the biology and management of a selected pulse beetle. Ph.D.Thesis, Manonmaniam Sundaranar University, Tirunelvely, India. 2007.

18) Nawrot J, Warchalewski JR, Kwiatkowska DP, Niewiada A, Gawlak M, Grundas ST, et al. The effect of some biochemical and technological properties of wheat grain on granary weevil Sitophilus granarius ( L.) (Coleoptera: Curculionidae) development. In: and others, editor. 9th International Working Conference on Stored Product Protection. 2006;p. 400-407.

19) Kavallieratos NG, Athanassiou CG, Vayias BJ, Kotzamanidis S, Synodis SD. Efficacy and adherence ratio of diatomaceous earth and spinosad in three wheat varieties against three stored-product insect pests. Journal of Stored Products Research. 2010;46(2):73-80. Available from: https://dx.doi.org/10. 1016/j.jspr.2009.10.003.

20) Athanassiou CG, Kavallieratos NG, Tsaganou FC, Vayias BJ, Dimizas CB, Buchelos CT. Effect of grain type on the insecticidal efficacy of SilicoSec against Sitophilus oryzae (L.) (Coleoptera: Curculionidae). Crop Protection. 2003;22(10):1141-1147. Available from: https://dx.doi.org/10.1016/s0261-2194(03) 00155-8.

21) Keskin S, Ozkaya H. Effect of Storage and Insect Infestation on the Mineral and Vitamin Contents of Wheat Grain and Flour. Journal of Economic Entomology. 2013;106(2):1058-1063. Available from: https://dx.doi.org/10.1603/ec12391.

22) n Nisa Yunus F, Asif K, Rashid F. Oviposition behavior of pulse beetle Callosobruchus chinensis (L) reared on different pulses and cereals. Biomedical Letters. 2015;1(1):5-8.

23) Akhtari N, Sardar MA, Rahman MH, Abedin SMZ, Rahman AKMM. Feeding and oviposition preference of pulse beetle, C. chinensis on different genotypes of bean and its control. Ann Bangladesh Agri. 1993;3(2):63-69.

24) Bashir T. Reproduction of Rhyzopertha dominica (F) (Coleoptera: Bostrichidae) on different host grains. Pakistan Journal of Biological Sciences. 2002;5:9193.

25) Edde PA, Phillips TW. Potential host affinities for the lesser grain borer, Rhyzopertha dominica: behavioral responses to host odors and pheromones and reproductive ability on non-grain hosts. Entomologia Experimentalis et Applicata. 2006;119(3):255-263. Available from: https://dx.doi.org/10.1111/ j.1570-7458.2006.00417.x.

26) Kumawat K. Effect of abiotic factors on biology of R.dominica (Fab.) on wheat. Annals of Plant Protection Sciences. 2007;15:111-115. 
27) Toews MD, Campbell JF, Arthur FH, Ramaswamy SB. Outdoor flight activity and immigration of Rhyzopertha dominica into seed wheat warehouses. Entomologia Experimentalis et Applicata. 2006;121(1):73-85. Available from: https://dx.doi.org/10.1111/j.1570-8703.2006.00462.x.

28) Jian F. Influences of stored product insect movements on integrated pest management decisions". Insects. 2019;10. Available from: https://doi.org/10. $3390 /$ insects 10040100.

29) Perisic V, Perisic V, Vukajlovic F, Pesic S, Predojevic D, Dekic V, et al. Feeding preferences and progeny production of Rhyzopertha dominica (Fabricius 1792) (Coleoptera: Bostrichidae) in small grains. Biologica Nyssana. 2018;9(1):55-61.

30) Jagannadham K, Valli RP, Babu S, Rao S. A study on comparision between cereal (wheat) and non cereal chickpea flour characteristics. Indian journal of Current Trends and Research. 2014;3(2):70-76.

31) Klys M. Nutritional preferences of the lesser grain borer Rhyzoperthadominica F. (Coleoptera, Bostrichidae) under conditions of free choice of food". Journal of Plant Product Research. 2006;48(4):360-367.

32) Naik SH, Mohankumar S, Naik O, Pallavi MS, Srinivasan MR, Chandrasekharan S. Influence of food sources on developmental period of Rhyzopertha dominica,Tribolium castaneum and Sitophilus oryzae". Indian Journal of Plant Protection. 2016;44(1):63-68.

33) Mahroof RM, Phillips TW. Life history parameters of Lasioderma serricorne (F.) as influenced by food sources. Journal of Stored Products Research. 2008;44(3):219-226. Available from: https://dx.doi.org/10.1016/j.jspr.2007.12.001.

34) Cornell HJ, Hoveling AW. Wheat: Chemistry and Utilization. Lancaster. Technomic Publishing Company. 1998.

35) Suits R, Reisig D, Burrack H. Feeding Preference and Performance ofHelicoverpa zea(Lepidoptera: Noctuidae) Larvae on Various Soybean Tissue Types. Florida Entomologist. 2017;100(1):162-167. Available from: https://dx.doi.org/10.1653/024.100.0123. 